\title{
Role of Calcium Channel Subtypes in Calcium Transients in Hippocampal CA3 Neurons
}

\author{
Elicia M. Elliott, ${ }^{1}$ Alfred T. Malouf, ${ }^{2}$ and William A. Catterall ${ }^{1}$ \\ Departments of ${ }^{1}$ Pharmacology and ${ }^{2}$ Neurological Surgery, University of Washington, Seattle, Washington 98195
}

\begin{abstract}
Multiple subtypes of voltage-gated calcium channels are differentially localized in brain neurons suggesting that they serve distinct roles in neuronal excitation and signaling. In organotypic hippocampal slice cultures, class D (Ltype) calcium channels are predominantly located in the cell bodies of CA3 neurons while class B ( $\mathrm{N}$-type) and class $A$ (P or Q-type) are locallzed In dendrites and assoclated presynaptic terminals with relatively low somal expression. Using specific antagonists to inhibit calcium transients recorded in CA3 neuronal cell bodies, we found that L-type calcium channels have a predominant role in somal calcium transients elicited by trains of strong stimuli applied to either the soma or the distal apical dendrite while class A calcium channels make a smaller contribution. Presynaptic class B (N-type) and class A (P- and/or Q-type) calcium channels are critical for glutamate-mediated synaptic transmission onto the dendrites of CA3 neurons. Postsynaptic class $A$ and $B$ calcium channels detected on the dendritic shaft by immunocytochemistry were not found to contribute substantially to somal calcium transients during repetitive stimulation of distal dendrites, but sodium channels were required for calcium transients elicited by somatic or dendritic stimulation. Our results show that the different calcium channel subtypes serve distinct roles in cellular activation and transmission of signals in CA3 neurons, consistent with their differential subcellular localization.
\end{abstract}

Calcium ions entering neurons through voltage-gated calcium channels initiate the physiological responses induced by action potentials. These include generation of calcium-dependent action potentials and spatial and temporal summation of multiple synaptic inputs in dendrites, activation of intracellular processes such as enzyme regulation and gene transcription in cell bodies, and release of neurotransmitters from nerve terminals. How are the voltage-gated calcium channels organized and regulated to carry out their roles in these diverse physiological functions?

\footnotetext{
Received Feb. 7, 1995; revised May 22, 1995; accepted June 2, 1995.

This work was supported by NIH Research Grant N\$22625, Pfizer, Inc., and the W. M. Keck Foundation (W.A.C.), by NIH Research Grant NS28650 and the PEW Memorial Trust (A.T.M.), and by a NINDS Postdoctoral Fellowship (E.M.E.). We thank Dr. Ruth E. Westenbroek for generous expert immunocytochemical advice, Dr. Michael K. Ahlijanian of Pfizer Central Research Laboratories for a generous gift of $\omega$-Aga-IVA, and Dr. Baldomero M. Olivera of the Department of Biology, University of Utah for a generous gift of $\omega$-CTxMVIIC.

Correspondence should be addressed to William A. Catterall at the above address.

Copyright (C) 1995 Society for Neuroscience $0270-6474 / 95 / 156433-12 \$ 05.00 / 0$
}

Voltage-gated calcium channels have been classified into at least five types ( $L, N, P, Q$, and $T$ ) based on electrophysiological and pharmacological criteria (Bean, 1989; Llinas et al., 1989; Hess, 1990; Hillman et al., 1991; Hillyard et al., 1992; Zhang et al., 1993; Randall et al., 1995). L-, N-, P-, and Q-type channels are all high-voltage-activated requiring a strong depolarization for activation, while T-type calcium channels are low-voltage-activated. L-Type channels mediate large single channel currents with slow rates of voltage-dependent inactivation and are specifically inhibited by the dihydropyridines. N-Type channels conduct single channel currents of intermediate size with a broad range of inactivation rates and are irreversibly inhibited by $\omega$-CTx-GVIA. P-Type channels also conduct single channel currents of intermediate size but have slow inactivation rates and are preferentially inhibited by low concentrations of $\omega$-Aga-IVA (Mintz et al., 1992a; Usowicz et al., 1992). Finally, Q-type channels conduct intermediate single channel currents, have faster inactivation rates than P-type, and arc prefcrentially inhibitcd by low concentrations of $\omega$-CTx-MVIIC (Sather et al., 1993; Randall et al., 1995).

Calcium channels from skeletal muscle which conduct L-type currents are composed of five distinct subunits: $\alpha 1, \alpha 2, \beta, \gamma$, and $\delta$ (Campbell et al., 1988; Catterall et al., 1988), and neuronal L-type and $N$-type calcium channels have $\alpha 1, \alpha 2, \beta$, and $\delta$ subunits (Ahlijanian et al., 1990; McEnery et al., 1991; Witcher et al., 1993; Leveque et al., 1994). The $\alpha 1$ subunit of L-type calcium channels from skeletal and cardiac muscle can form a functional channel indicating that it contains the calcium-selective pore, gating mechanisms, and sites for the pharmacological antagonists (Mikami et al., 1989; Perez-Reyes et al., 1989). In rat brain, several classes of calcium channel $\alpha 1$ subunits have been defined by cDNA cloning and sequencing in neurons and are designated A, B, C, D, and E (Snutch et al., 1990; Snutch and Reiner, 1992; Soong et al., 1993; Zhang et al., 1993). The class $\mathrm{C}$ and $\mathrm{D} \alpha 1$ subunits both conduct L-type calcium currents (Snutch et al., 1990; Hui et al., 1991; Williams et al., 1992a; Tomlinson et al., 1993), while the class B $\alpha 1$ subunit forms N-type calcium channels (Dubel et al., 1992; Williams et al., 1992b; Fujita et al., 1993). When expressed in Xenopus oocytes, the class $\mathrm{A} \alpha 1\left(\alpha 1_{\mathrm{A}}\right)$ subunit forms calcium channels that are blocked by $\omega$-CTx MVIIC and by high concentrations of $\omega$-AgaIVA, and resemble Q-type (Sather et al., 1993). However, alternatively spliced forms of $\alpha 1_{A}$ can form calcium channels which inactivate rapidly like Q-type or slowly like P-type channels (Stea et al., 1994), and $\alpha 1_{A}$ is localized at sites in the cerebellum which contain mainly P-type calcium currents (e.g., Purkinje cell bodies) and at sites which contain mainly Q-type currents (e.g., granule cells and their nerve terminals) (preceding article, Wes- 
tenbroek et al., 1995). These results raise the possibility that the class $\mathrm{A} \alpha 1$ subunit is a component of calcium channels conducting both the closely related P-type and Q-type calcium currents.

Site-directed anti-peptide antibodies recognizing the different $\alpha 1$ subunits have been used to investigate the cellular and subcellular distribution of the calcium channels in rat brain. In CA3 hippocampal pyramidal cells, L-type channels containing $\alpha 1_{C}$ and $\alpha 1_{D}$ are predominantly located in the cell body and proximal dendrites (Ahlijanian et al., 1990; Westenbroek et al., 1990; Hell et al., 1993) whereas the $\mathrm{N}$-type calcium channels containing $\alpha 1_{B}$ and the P/Q-type channels containing $\alpha 1_{A}$ are predominantly found along the length of the apical dendrites and in nerve terminals forming synapses upon them (Westenbroek et al., 1992, 1995). This differential localization of calcium channels implies that each channel class may contribute differentially to intracellular calcium transients and therefore to initiation of distinct physiological events, but the relationship between channel localization and physiological role has not been established. In the experiments described here, we have examined the distinct roles of calcium channel $\alpha 1$ subunits located in cell bodies, dendrites, and presynaptic terminals in the generation of calcium transierts in hippocampal CA3 neurons in response to somal and dendritic stimulation using organic and peptide antagonists to block calcium channel function.

\section{Materials and Methods}

Hippocampal slice cultures. Hippocampal slice cultures were prepared from $4 \mathrm{~d}$ old Sprague-Dawley rats by the roller-tube method of Gähwiler (Gähwiler, 1981; Malouf et al., 1990). The slices were utilized after $10-18 \mathrm{~d}$ in vitro at which point the slices had flattened from 400 $\mu \mathrm{m}$ to $80-100 \mu \mathrm{m}$ so that individual neurons could be viewed with phase-contrast microscopy.

Immunocytochemistry. Hippocampal slice cultures were fixed with a solution of $4 \%$ paraformaldehyde and $0.2 \%$ glutaraldehyde in $0.1 \mathrm{M}$ sodium phosphate buffer (PB; pH 7.4) for $2-3 \mathrm{hr}$ at $4^{\circ} \mathrm{C}$. The slices were then rinsed with $10 \%$ sucrose in $\mathrm{PB}$ and incubated overnight at $4^{\circ} \mathrm{C}$ in $30 \%$ sucrose in PB. Sections $(40 \mu \mathrm{m})$ were cut on a sliding microtome. Free-floating sections were processed for immunocytochemistry with the $\mathrm{ABC}$ technique at room temperature unless otherwise noted.

On day 1, tissue was sequentially incubated in: (1) $0.1 \mathrm{M}$ Tris- $\mathrm{HCl}$ (TB, $\mathrm{pH} \mathrm{7.4)} \mathrm{for} 15 \mathrm{~min}$, (2) $1 \%$ sodium borohydride in TB for $30-60$ min, (3) $0.1 \mathrm{M}$ Tris- $\mathrm{HCl}$ saline (TBS, $\mathrm{pH} \mathrm{7.4)} \mathrm{for} 40 \mathrm{~min}$, (4) avidin blocking solution (Vector, CA) for $20 \mathrm{~min}$, (5) TBS for $10 \mathrm{~min}$, (6) biotin blocking solution (Vector, CA) for $20 \mathrm{~min}$, (7) TBS for $25 \mathrm{~min}$, (8) a solution of $1-10 \%$ normal goat serum (NGS), $0.05-0.5 \%$ Triton $\mathrm{X}-100$, and $0.1 \%$ bovine serum albumin (BSA, optional) in $0.05 \mathrm{M}$ TBS for $2 \mathrm{hr}$, (9) TBS for $25 \mathrm{~min}$, and (10) a solution of 1-10\% NGS, 0.05 $0.5 \%$ Triton $\mathrm{X}-100,0.1 \% \mathrm{BSA}$ (optional), and affinity purified calcium channel antibody (CNA1 diluted at 1:15, CNB2 diluted at 1:30, or CND1 diluted at $1: 25$; Westenbroek et al., 1990; 1992, 1995) in 0.05 M TBS for $72 \mathrm{hr}$ at $4^{\circ} \mathrm{C}$.

On day 4 , tissue exposed to the CNB2 and CND1 antibodies were sequentially incubated in: (1) TBS for $25 \mathrm{~min}$, (2) a solution of $1-10 \%$ NGS, $0.05-0.5 \%$ Triton X-100, 0.1\% BSA (optional), and biotinylated goat anti-rabbit IgG (BGAR) diluted at 1:300 in $0.05 \mathrm{M}$ TBS for $2 \mathrm{hr}$, (3) TBS for $25 \mathrm{~min}$, (4) ABC reagent (Vector, CA) in $0.05 \mathrm{M}$ TBS for $3 \mathrm{hr}$, (5) TBS for $15 \mathrm{~min},(6) \mathrm{TB}$ for $10 \mathrm{~min},(7)$ a solution of $0.005 \%$ nickel and $0.05 \%$ 3, $3^{\prime}$-diaminobenzidine (DAB) in TB for $10 \mathrm{~min}$, (8) the above solution with $0.003 \% \mathrm{H}_{2} \mathrm{O}_{2}$ for $10 \mathrm{~min}$, and (9) $\mathrm{TB}$ for $1 \mathrm{hr}$. The tissue was mounted on subbed glass slides, dehydrated, cleared in xylene, and coverslipped.

The more sensitive immunocytochemical technique, Biotin Amplification Procedure, was utilized to visualize the CNA1 immunocytochemical staining. On day 4, tissue exposed to the CNA1 antibody was treated as described in Berghorn et al. (1993) with the following modifications: (1) TBS was used as the buffer, and (2) the BGAR was diluted at $1: 4000$.

Control sections were processed as described above but without the primary antibody to determine the level of nonspecific staining within the hippocampal slice. In all cases, the staining patterns reported here were abolished in these control sections.

Electrophysiology. The coverglass on which the slice was grown, served as the base of a stainless steel chamber which allowed perfusion ( $1 \mathrm{ml} \mathrm{vol} ; 0.5 \mathrm{ml} / \mathrm{min}$ flow rate) and temperature maintenance at $35^{\circ} \mathrm{C}$ (ATR-4 Adaptable Thermoregulator, Fine Science Tools, Can.). The chamber was attached to the stage of a Nikon inverted microscope (Diaphot-TMD-EF with the epifluorescence attachment) placed on a MI$\mathrm{CRO}-\mathrm{g}$ vibration isolation table (Technical Manufacturing Corporation, MA). The cultures were perfused with Hanks' Balanced Salt Solution (GIBCO), in mM: $\mathrm{CaCl}_{2} 1.3, \mathrm{KCl} \mathrm{5,} \mathrm{KH}_{2} \mathrm{PO}_{4} 0.3, \mathrm{MgCl}_{2} 0.5, \mathrm{MgSO}_{4} 0.4$, $\mathrm{NaCl} 138, \mathrm{Na}_{2} \mathrm{HPO}_{4} 0.3$, and D-glucose 5.6 , with $4.16 \mathrm{mM} \mathrm{NaHCO}_{3}$ added.

Intracellular recording of individual $\mathrm{CA} 3$ pyramidal neurons was made using fine tipped intracellular electrodes filled with $12 \mathrm{~mm}$ fura-2 pentapotassium salt (Molecular Probes, OR) in $1 \mathrm{~m}$ potassium acetate (pH 7.3). A Physik Instruments manipulator was used to impale the neuron. Total electrode resistance was 75-100 $\Omega$. Neurons were filled by applying $-0.5 \mathrm{nA}$ current for $10 \mathrm{~min}$ using a Neuro Data Intracellular Recording Amplifier (model IR-283; NY), a Neuro Data Digital Stimulator (model PG 4000A), and a Tektronix Oscilloscope (model 5113; OR). All injected neurons had membrane potentials more negative than $-55 \mathrm{mV}$, responded to small depolarizations with a repetitive action potential discharge, and had resting free calcium levels of 40 $60 \mathrm{nM}$.

Neurons were filled to less than $50 \mu \mathrm{M}$ fura-2 based on a comparison of the somal fluorescence with the fluorescence of calibration solutions of known path length and dyc concentration. This fura-2 concentration has nominal effects on cell firing properties (Regehr and Tank, 1992). Following fura-2 injection, the intracellular electrode was removed and a concentric bipolar stimulating electrode ( $25 \mu \mathrm{m}$ spacing) was placed, guided by neuronal fluorescence, at a position $5-10 \mu \mathrm{m}$ above the soma or a position $5-10 \mu \mathrm{m}$ above the apical dendrite $200-300 \mu \mathrm{m}$ from the soma. The experimental stimulus train was $20 \mathrm{~Hz}$ for $10 \mathrm{sec}, 100 \mu \mathrm{sec}$ pulse duration, and 100-200 $\mu \mathrm{A}$, delivered with a Neuro Data stimulus isolation unit (model SIU90). Neurons were stimulated at $10 \mathrm{~min}$ intervals as preliminary experiments demonstrated that neuronal responses were consistent in amplitude for over $80 \mathrm{~min}$ with this paradigm. At least two control responses were obtained for each cell. All drugs were perfused onto the slice for $10 \mathrm{~min}$.

Calcium imaging. Experiments were conducted in the W. M. Keck Center for Advanced Research in Neural Signaling. A 75 W xenon lamp and a Metaltek (NC) filter wheel and shutter were separated from the microscope to prevent vibration from affecting the optical and physiological recordings. A G. W. Ellis tiberopic light scrambler (Technical Video Ltd., MA) was used to transmit the light to the microscope. Excitation, emission, and neutral density filters were from Omega Optical (VT). The objectives used were a Nikon Fluor 40/1.3 NA oil and a Nikon Fluor 40/0.85 NA. The images were intensified with a GenIIsys Image Intensifier (Dage-MTI, IN) and acquired with a Dage-MTI CCD72 Series camera. All image acquisition was computer controlled with the Universal Imaging Corporation's (PA) IMAGE-1/FL program. Images were viewed on a Sony Trinitron color video monitor (PVM-1343MD) and printer (UP-5000) and a Javelin Electronics video monitor (model BWM9x, CA) and stored via a Panasonic optical disk drive (LF-7010) Images were acquired at $2-3 \mathrm{sec}$ intervals to reduce photobleaching. Preliminary experiments verified the linearity of the fura- 2 response at the camara settings utilized in these experiments. In vitro calibrations were performed with $1 \mu \mathrm{M}$ fura-2 and a saline approximating intracellular conditions ( $100 \mathrm{mM} \mathrm{KCl}, 10 \mathrm{~mm}$ MOPS, $1 \mathrm{~mm}$ free $\mathrm{Mg}$; $\mathrm{pH} 7.2$, $\left.35^{\circ} \mathrm{C}\right)$ with balanced EGTA $(10 \mathrm{~mm})$ and CaEGTA $(10 \mathrm{~mm})$ concentrations to yield $0 \mathrm{mM}$ and $37.9 \mu \mathrm{M}$ free $\left[\mathrm{Ca}^{2+}\right]_{i}$ (Elliott and Sapolsky, 1992, 1993).

All images were corrected for background fluorescence and shading across the field of view. A background image acquired adjacent to the fura-2 loaded neuron, was subtracted from all experimental images. A shading image was acquired using $10.8 \mu \mathrm{M}$ fura- 2 to emphasize nonuniformities across the field of view. Conversion of the ratio of the fluorescent intensities at each excitation wavelength $(340 \lambda$ and $380 \lambda)$ to neuronal $\left[\mathrm{Ca}^{2+}\right]_{i}$ was determined through standard equations (Grynkiewicz et al., 1985). $R_{\min }$ was determined using $10.8 \mu \mathrm{M}$ fura- 2 in the intracellular saline described above with $10 \mathrm{mM}$ free EGTA. $R_{\max }$ was determined with a similar solution using $10 \mathrm{~mm}$ CaEGTA. The fura-2 $K_{d}$ of 224 nM was utilized based on the temperature and ionic strengths of the solutions

Antagonists. Many antagonists were utilized in this investigation, 

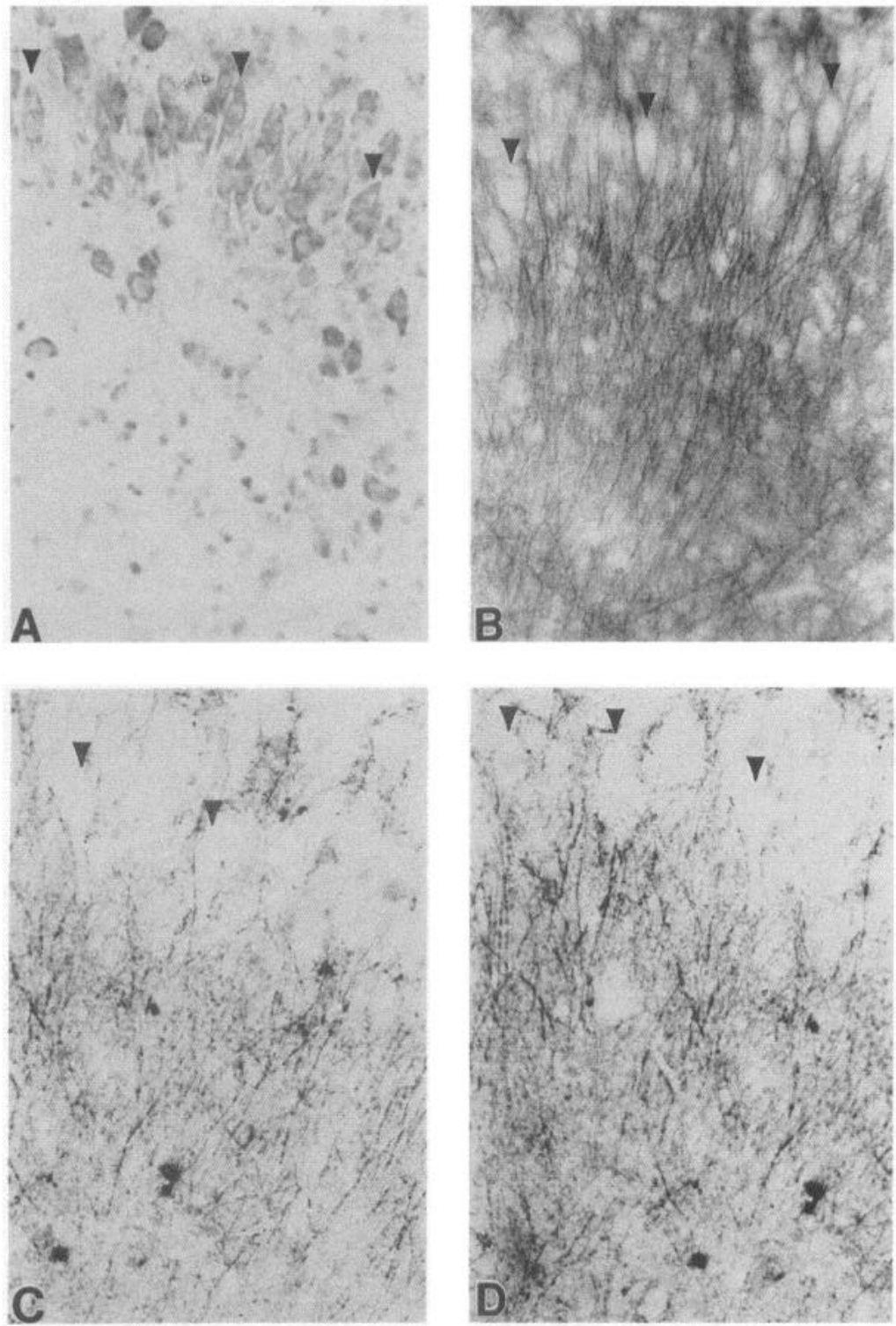

Figure 1. Differential calcium channel localization in CA3 neurons in the cultured hippocampal slice. Area CA3 of hippocampal slice cultures was stained with antibodies to the $\alpha 1$ subunits of class A, B, and D calcium channels. A, Class D (L-type) is predominantly located on the cell body and proximal apical dendrites. $B$, Class $\mathrm{B}$ (N-type) is predominantly located on the apical dendrites. $C$ and $D$, Class A (P/Q-type) is predominantly located on the apical dendrites with a superimposed punctate distribution and a lower level of somal expression. Arrowheads indicate the pyramidal cell bodies. Magnification, $176 \times$. none of which fluoresced at the same wavelengths as fura- 2 . All perfusion tubing was precoated with $1 \mathrm{mg} / \mathrm{ml}$ BSA and all peptide antagonist solutions included $1 \mathrm{mg} / \mathrm{ml} \mathrm{BSA}$ to minimize nonspecific peptide binding. The diluents and concentrations utilized were: 5 -amino-4-phosphonovalerate (DL-AP5, Sigma, distilled water, $100 \mu \mathrm{M}$ ), 6-cyano-7nitroquinoxaline-2,3-dione (CNQX, RBI, distilled water, $50 \mu \mathrm{M}$ ), tetrodotoxin (TTX, Calbiochem, distilled water, $10 \mu \mathrm{M}$ ), nimodipine [gift of Miles Inc., dimethylsulfoxide (DMSO), $1 \mu \mathrm{M}]$, isradipine (gift of Sandoz Research Institute, DMSO, $1 \mu \mathrm{M})$, $\omega$-CTx-GVIA (Bachem CA, distilled water, $5 \mu \mathrm{M}$ ), $\omega$-Aga-IVA (gift of Dr. M. K. Ahlijanian of Pfizer, distilled water, 30-500 nM), and $\omega$-CTx-MVIIC (gift of Dr. B. Olivera, distilled water, $1.5 \mu \mathrm{M}$ ). Solutions in which DMSO was added as a diluent included $0.05 \%$ DMSO final concentration which had no effect on the measured calcium transients.

Statistics. The peak $\left[\mathrm{Ca}^{2+}\right]$, response within the CA3 neuronal soma was obtained under control and experimental (drug) conditions for each cell. Data were then expressed as mean $\left[\mathrm{Ca}^{2+}\right]_{i}$ peak as a percentage of the mean control $\left[\mathrm{Ca}^{2+}\right]_{i}$ peak. Data were statistically analyzed by paired $t$ tests.

\section{Results}

Differential calcium channel localization in CA3 neurons in organotypic cultures of hippocampal slices

Organotypic cultures of hippocampal slices are a favorable preparation for studies of the functional significance of differential calcium channel distribution in neurons because they retain much of the morphology and synaptic connectivity of the intact hippocampus yet are thin enough $(80-100 \mu \mathrm{m})$ for direct observation of individual neurons (Gähwiler, 1981; Frotsher and Gähwiler, 1988; Dailey et al., 1994). These features facilitate the use of optical recording techniques to examine the physiology of intact hippocampal neurons. Previous experiments using a panel of site-directed anti-peptide antibodies demonstrated distinct distributions of the different calcium channel $\alpha 1$ subunits in adult rat hippocampal neurons (Westenbroek et al., 1990, 1992, 1995). Similar methods were used to examine the distribution of calcium channels in CA3 pyramidal neurons from cultured hippocampal slices. As in adult tissue, the class D, L-type calcium channel identified by anti-CND1 is located predominantly on the cell body with little expression along the apical dendrites (Fig. 1A). In contrast, the class $\mathrm{B}, \mathrm{N}$-type calcium channel identified by anti-CNB2 is located predominantly along the apical dendrites with very little somal expression (Fig. 1B). Higher magnification revealed a punctate distribution consistent with labeling of mossy fiber nerve terminals forming synapses 
on CA3 dendrites as observed in adult hippocampus (Westenbroek et al., 1992). The class A, P/Q-type channels identified by anti-CNA1 are also primarily localized on dendrites with a substantially lower level of somal expression (Fig. 1C,D), and a punctate distribution is observed at higher magnification as in adult hippocampus (Westenbroek et al., 1995). Thus, the complementary localization of calcium channels in CA3 hippocampal neurons is retained in the hippocampal slice culture preparation, suggesting that this preparation would be useful for investigation of the distinct roles of these calcium channels during neuronal activation and signal transduction in intact cells.

\section{Calcium transients in the cell bodies of CA3 neurons in slice cultures}

In order to examine the response of intact hippocampal neurons to physiologically relevant stimuli, we measured calcium transients in the cell bodies of neurons in response to extracellular stimuli which elicited trains of synaptic potentials and action potentials. One CA3 neuron per slice was filled with fura- 2 pentapotassium salt using a sharp microelectrode (Fig. 2A,B). A bipolar stimulating electrode was placed either at the cell body or $200-300 \mu \mathrm{m}$ along the apical dendrite using the cellular fluorescence to visually guide the electrode placement. Filled cells were stimulated with a $20 \mathrm{~Hz}$ train of impulses for $10 \mathrm{sec}$ at an intensity sufficient to produce a transient increase in somal calcium from the resting level of $40-60 \mathrm{nM}$ to a peak of $100-500$ $\mathrm{nM}$, similar to the values observed in CA1 hippocampal neurons in acutely dissected hippocampal slices (Regehr et al., 1989; Regehr and Tank, 1992). The peak somal $\left[\mathrm{Ca}^{2+}\right]_{i}$ response did not differ significantly following somal or apical stimulation $(321 \pm 58 \mathrm{nM}, n=43$ and $407 \pm 17 \mathrm{nM}, n=145$, respectively, $t>0.05$, unpaired $t$ test). The somal $\left[\mathrm{Ca}^{2+}\right]_{i}$ increases within 2 $\mathrm{sec}$, reaches a maximum within $4 \mathrm{sec}$, and then rapidly declines (Fig. 2C). This stimulus train was applied at 10 min intervals which allowed recording of seven or eight repetitive somal $\left[\mathrm{Ca}^{2+}\right]_{i}$ responses over $70-80 \mathrm{~min}$.

Loss of normal resting membrane potential is a concern when studying neurons that have been impaled by a sharp microelectrode. All cells studied retained a resting membrane potential more negative than $-55 \mathrm{mV}$ after impalement. Several lines of evidence indicated that they maintained resting membrane potentials at least that negative throughout the experiments. (1) Resting calcium levels of $40 \mathrm{nM}$ to $60 \mathrm{~nm}$ were recorded throughout the experiments. Calcium levels returned to the resting level of 40-60 nM repeatedly after transients as high as 500 nM. These low intracellular calcium levels are not consistent with depolarized cells because depolarization beyond $-55 \mathrm{mV}$ would activate L-type calcium channels yielding persistent calcium influx, high intracellular calcium, and cell deterioration. For unhealthy cells, calcium rises to greater than $1 \mu \mathrm{M}$ and does not return to resting levels. (2) Our results (see below) show that activation of voltage-gated sodium channels is required for generation of calcium transients. Sodium channels in brain neurons are nearly completely inactivated at membrane potentials more positive than $-60 \mathrm{mV}$. Thus, the robust sodium channel-dependent responses that we observed throughout the course of these experiments imply that the membrane potentials were more negative than $-60 \mathrm{mV}$. (3) We consistently recorded full-size ( 80 $\mathrm{mV}$ ) action potentials in response to stimulation of the cells. This also requires the activity of sodium channels and implies a membrane potential more negative than $-60 \mathrm{mV}$. On the basis of these results, we conclude that the $\mathrm{CA} 3$ neurons we have
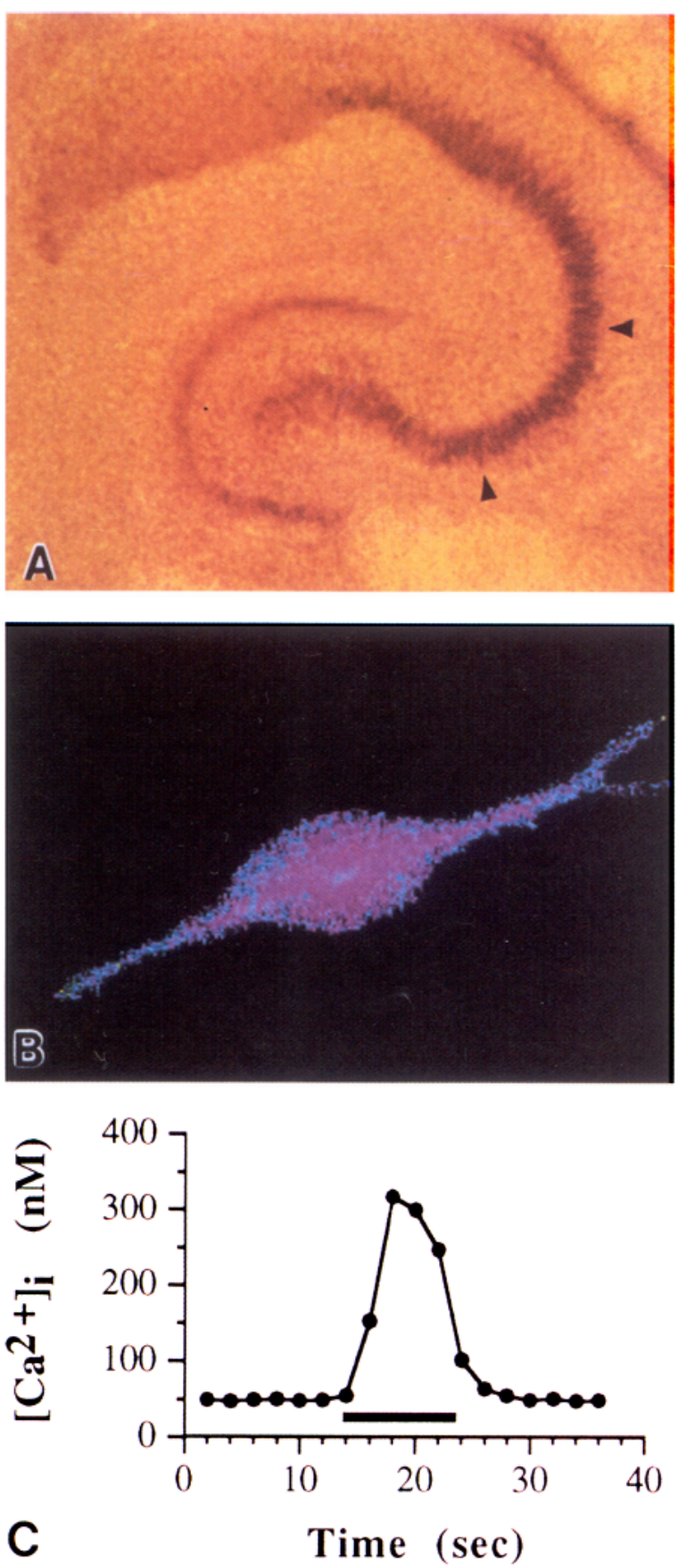

Figure 2. Physiologically induced somatic calcium transients in CA3 neurons in hippocampal slice cultures. $A$, Hippocampal slice culture stained with cresyl violet to indicate the pyramidal cell body layer. CA3 neurons utilized in this study are indicated between the two arrowheads. $B$, Typical CA3 neuron filled with fura-2 with a basal calcium concentration of 40-60 nм. $C$, Typical somatic calcium response to stimulation of the distal end of the apical dendrites approximately $200 \mu \mathrm{m}$ from the cell body with a $20 \mathrm{~Hz}$ train (indicated by the solid bar). Magnification: $40 \times(A), 341 \times(B)$.

studied in these experiments retain a resting membrane potential more negative than $-60 \mathrm{mV}$ and generate physiologically significant responses to synaptic and directly depolarizing stimuli.

\section{Somal $\left[\mathrm{Ca}^{2+}\right]_{\mathrm{i}}$ transient elicited by somal stimulation}

During somal stimulation, the bipolar electrode was placed 5$10 \mu \mathrm{m}$ above the cell body and the stimulus-induced somal 
Figure 3.
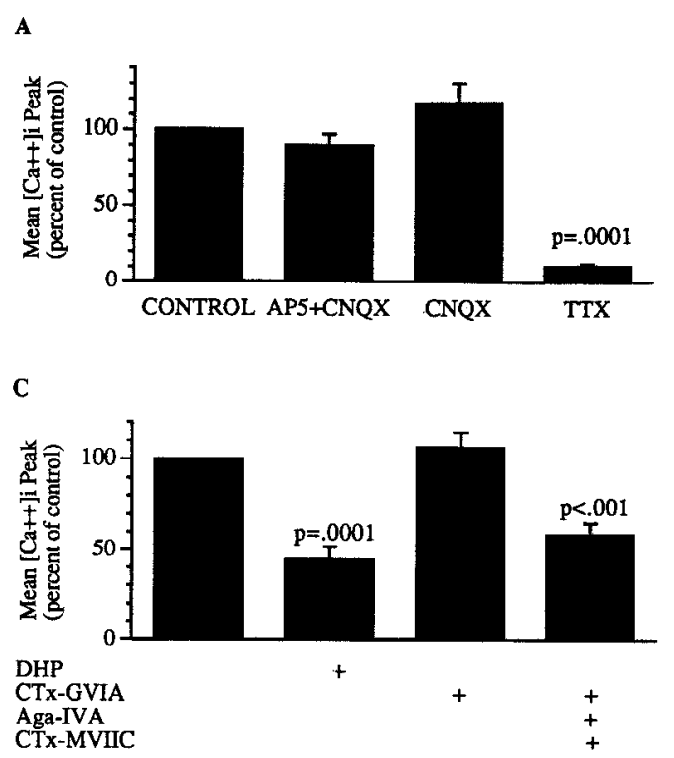

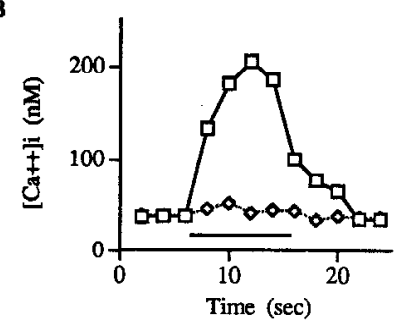

D

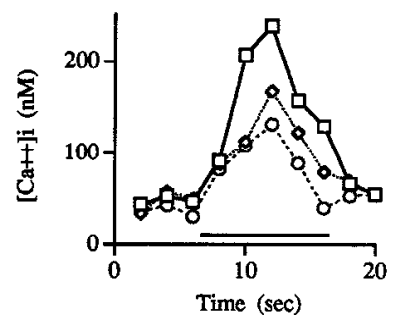

Figure 3. Class C and D L-type and class A calcium channels contribute to the somal $\left[\mathrm{Ca}^{2+}\right]_{i}$ transient following somal stimulation. The somal $\left[\mathrm{Ca}^{2+}\right]_{i}$ transient was measured during somal stimulation as described in Materials and Methods. A, Antagonists to glutamate-mediated synaptic transmission (AP5 and $C N Q X)$ have no effect on the somal $\left[\mathrm{Ca}^{2+}\right]_{i}$ transient whereas an antagonist to sodium channels (TTX) greatly reduces the $\left[\mathrm{Ca}^{2+}\right]$ transient. $B$, Representative somal $\left[\mathrm{Ca}^{2+}\right]_{i}$ transients for control $(\square)$ and TTX $(\diamond)$ for experiments presented in $A$. C, Class C and D L-type calcium channel antagonists $(D H P)$ and class A P/Q-type calcium channel antagonists (100 nM Aga IVA plus $\omega$-CTx-MVIIC) significantly inhibit the somal $\left[\mathrm{Ca}^{2+}\right]_{i}$ transient whereas the class B N-type channel antagonist ( $\omega$-CTx-GVIA) has no effect. $D$, Representative somal $\left[\mathrm{Ca}^{2+}\right]_{i}$ transients for control ( $\square$ ), (n-CTX-GVIA, (n-Aga-IVA, and (n-CTx-MVIIC ( $\diamond)$, and isradipine or nimodipine $(O)$ for experiments presented in $C$. Statistical comparisons indicated above each bar were made as follows: DHP versus none; $\omega$-CTx-GVIA versus none; and $\omega$-CTx-MVIIC, $\omega$-Aga-IVA, and $\omega$-CTx-GVIA versus $\omega$-CTx-GVIA. Antagonist concentrations for this and subsequent figures (except Fig. 5) were $100 \mu \mathrm{M}$ AP5, $50 \mu \mathrm{M}$ CNQX, $10 \mu \mathrm{M}$ TTX, $1 \mu \mathrm{M}$ nimodipine and isradipine (L-type channel antagonists, DHP), $5 \mu \mathrm{M} \omega$-CTX-GVIA (class B, N-type channel antagonist), and $100 \mathrm{nM} \omega$-Aga-IVA plus $1.5 \mu \mathrm{M} \omega$-CTx-MVIIC (class A, P/Q-type channel antagonists).

$\left[\mathrm{Ca}^{2+}\right]_{i}$ transient, averaged over the whole cell body, was measured. The values for the peak $\left[\mathrm{Ca}^{2+}\right]_{i}$ in the presence of inhibitors of glutamate receptors or calcium channels from experiments on multiple cells in separate slice cultures were averaged and compared to control values (Fig. 3). Inhibition of glutamatemediated synaptic transmission by the NMDA and non-NMDA antagonists AP5 and CNQX had no effect on the somal $\left[\mathrm{Ca}^{2+}\right]_{i}$ transient (Fig. $3 A, n=8$ ). In contrast, inhibition of sodium channels with TTX blocked $90 \%$ of the somal $\left[\mathrm{Ca}^{2+}\right]_{i}$ transient such that the remaining transient was $10 \pm 2 \%$ of the control (Fig. $3 A, n=5$; Fig. $3 B$ ). Thus, following somal stimulation, the somal $\left[\mathrm{Ca}^{2+}\right]_{i}$ response results from activation of sodium and calcium channels and does not require excitatory synaptic transmission.

Immunocytochemical studies have defined distinct localizations of the different classes of calcium channel $\alpha 1$ subunits. In order to examine the contribution of these different $\alpha 1$ subunits to calcium transicnts, wc used organic and peptide calcium channel antagonists which preferentially inhibit calcium channels containing different classes of $\alpha 1$ subunits. Because the specificity of the available drugs and toxins is not absolute, only a partial resolution of the contributions of different classes of calcium channel $\alpha 1$ subunits can be made. The dihydropyridines (DHP; nimodipine or isradipine) block L-type calcium channels containing $\alpha 1_{C}$ or $\alpha 1_{D}$ so that their contributions are measured together. $\omega$-CTX-GVIA is specific for N-type calcium currents mediated by calcium channels containing $\alpha 1_{B}$ under the conditions of our experiments so that their contribution can be accurately defined. Both $\omega$-Aga-IVA and $\omega$-CTx-MVIIC inhibit calcium channels containing $\alpha 1_{A}$, and both P-type and Q-type cal- cium currents may be due to channels which contain this subunit (Stei et al., 1994; Westenbroek et al., 1995). Thus, calcium transients inhibited by the combination of these two toxins reflect contributions of class A calcium channels. To ensure that inhibition of class $B$ channels by these toxins did not affect our measurements of calcium transients due to class A channels, we always applied $\omega$-Aga-IVA and $\omega$-CTX-MVIIC after prior application of $\omega$-CTX-GVIA. Although P-type and Q-type calcium currents are not completely resolved by a single concentration of $\omega$-Aga-IVA or $\omega$-CTx-MVIIC, an estimate of their contributions to these calcium transients can be madc by study of the concentration dependence of the action of $\omega$-Aga-IVA (see below).

Antagonists of each molecular class of voltage-sensitive calcium channel had different effects on the stimulus-induced somal $\left[\mathrm{Ca}^{2+}\right]_{i}$ transients. The dihydropyridine L-type channel antagonists isradipine and nimodipine inhibited $56 \%$ of the stimulus-induced somal $\left[\mathrm{Ca}^{2+}\right]_{i}$ transient such that the remaining transient was $44 \pm 8 \%$ of control (Fig. $3 C, n=13$; Fig. $3 D$ ). In contrast, the N-type channel antagonist $\omega$-CTx-GVIA had no effect on the stimulus-induced somal $\left[\mathrm{Ca}^{2+}\right]_{i}$ transient (Fig. $3 C$, $n=15$ ). Thus, the class $\mathrm{C}$ and $\mathrm{D}$ channels, which our immunocytochemical studies show to be preferentially localized on the neuronal soma, contribute substantially to the somal calcium transient. The class B channels, which are present in a low density in the cell soma, do not contribute detectably to the somal calcium transient.

We used $\omega$-Aga-IVA (100 nM) and $\omega$-CTx-MVIIC (1.5 $\mu \mathrm{M})$ to estimate the component of the intracellular calcium transients that was due to class A calcium channels. With class B channels 
Figure 4.
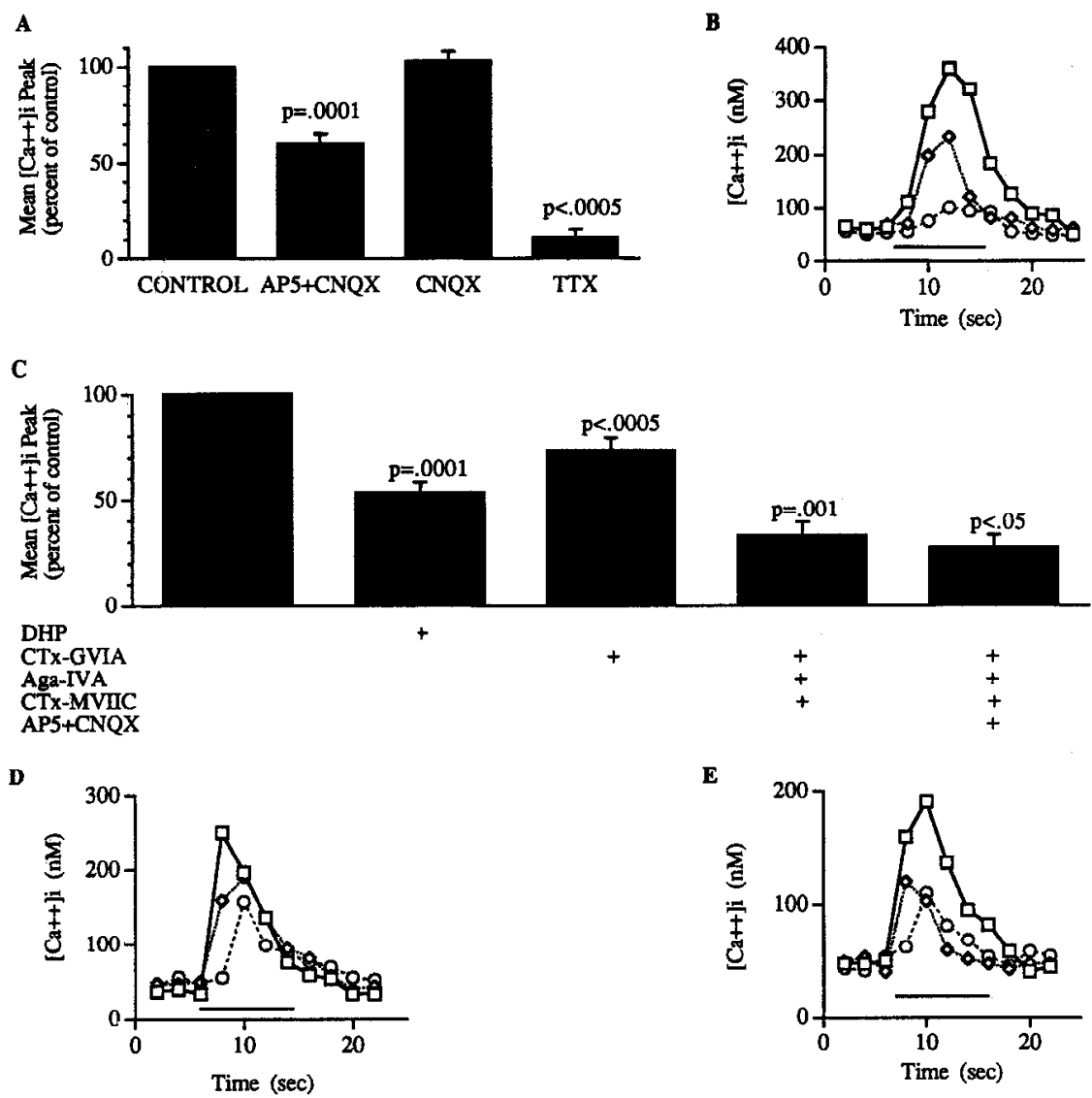

Figure 4. Class $\mathrm{C}$ and D L-type, class B N-type, and class A P/Q-type channels contribute to the somal [Ca $\left.{ }^{2+}\right]_{i}$ transient following dendritic stimulation. The somal $\left[\mathrm{Ca}^{2+}\right]$ transient was measured during apical dendritic stimulation. $A$, In contrast to that following direct somal stimulation, antagonists to glutamatc-mediatcd synaptic transmission $(\Lambda P 5$ and $C N Q X)$ inhibit the somatic $\left[\mathrm{Ca}^{2+}\right]_{i}$ transient. Inhibition of only the non-NMDA subtype of glutamate receptors $(C N Q X)$ has no effect on the $\left[\mathrm{Ca}^{2+}\right]_{i}$ transient. Similar to that following somal stimulation, an antagonist of sodium channels $(T T X)$ greatly reduces the somal $\left[\mathrm{Ca}^{2+}\right]_{i}$ transient. $B$, Representative somal $\left[\mathrm{Ca}^{2+}\right]_{i}$ transients for control $(\square)$, AP5 $+\mathrm{CNQX}(\diamond)$, and TTX $(O)$ for experiments presented in $A$. $C$, The indicaled antagunists of class A-D calcium channels all significantly inhibit the somal $\left[\mathrm{Ca}^{2+}\right]_{i}$ transient. Antagonists to glutamate-mediated synaptic transmission (AP5 and $C N Q X)$ caused a small but significant reduction in the somal $\left[\mathrm{Ca}^{2+}\right]_{i}$ transient even in the presence of antagonists of the class A and B calcium channels. $D$, Representative somal [Ca $\left.{ }^{2+}\right]_{i}$ transients for control $(\square)$, $\omega$-CTX-GVIA $(\diamond)$, and DHP $(O)$, from the experiments presented in $C$. E, Representative somal $\left[\mathrm{Ca}^{2+}\right]_{i}$ transients for $\omega$-CTx-GVIA $(\square)$; $\omega$-CTXGVIA, $\omega$-Aga-IVA, and $\omega$-CTx-MVIIC $(\diamond)$; and $\omega$-CTX-GVIA, $\omega$-Aga-IVA, $\omega$-CTx-MVIIC, and AP5 + CNQX $(O)$ from experiments presented in $C$. Statistical comparisons indicated above each bar were made as follows: DHP versus none; $\omega$-CTX-GVIA versus none; $\omega$-CTX-MVIIC, $\omega$-AgaIVA, and $\omega$-CTx-GVIA versus $\omega$-CTx-GVIA; and $\omega$-CTx-MVIIC, $\omega$-Aga-IVA, $\omega$-CTx-GVIA, and AP5 + CNQX versus $\omega$-Aga-IVA, $\omega$-CTx-GVIA, and $\omega$-CTx-MVIIC

blocked by $\omega$-CTx-GVIA, treatment with $\omega$-Aga-IVA followed by $\omega$-CTx-MVIIC further reduced the stimulus-induced somal $\left[\mathrm{Ca}^{2+}\right]_{i}$ transient to $59 \pm 7 \%$ of the control (Fig. $3 C, n=6$; Fig. $3 D$ ). Thus, calcium channels containing $\alpha 1_{\mathrm{A}}$ accounted for $41 \%$ of the peak calcium transient. Our immunocytochemical studies indicate that class $A \alpha 1$ subunits are present at an intcrmediate density on the cell soma relative to the class $C$ and D L-type channels and the class B N-type channels. Consistent with this localization, their inhibition causes an intermediate reduction in the somal calcium transient.

\section{Somal $\left[\mathrm{Ca}^{2+}\right]_{\mathrm{i}}$ transients elicited by apical dendritic stimulation}

During dendritic stimulation, the bipolar electrode was placed 5-10 $\mu \mathrm{m}$ above the distal apical dendrite at a point $200-300$ $\mu \mathrm{m}$ from the cell body, stimuli were applied that elicited a train of action potentials as recorded with an intracellular electrode in the cell body (not shown), and stimulus-induced somal $\left[\mathrm{Ca}^{2+}\right]_{i}$ transients were measured. In contrast to our results with somal stimulation, inhibition of glutamate-mediated synaptic transmission with the antagonists AP5 and CNQX reduced the somal $\left[\mathrm{Ca}^{2+}\right]_{i}$ response to apical dendritic stimulation to $60 \pm 5 \%$ of the control transient (Fig. $4 A, n=62$; Fig. $4 B$ ). This reduction was primarily due to inhibition of NMD $\Lambda$ receptors since CNQX, which inhibits non-NMDA receptors, had no effect on the somal $\left[\mathrm{Ca}^{2+}\right]_{i}$ transient when tested alone (Fig. $4 A, n=3$ ). Similar to our results following somal stimulation, sodium channel inhibition with TTX blocked $89 \%$ of the dendritic stimulusinduced somal $\left[\mathrm{Ca}^{2+}\right]_{i}$ transient such that the remaining transient was $11 \pm 4 \%$ of the control transient (Fig. $4 A, n=4$; Fig. $4 B$ ). Thus, following dendritic stimulation, the somal $\left[\mathrm{Ca}^{2+}\right]_{i}$ response results from both direct dendritic stimulation and glutamate-mediated synaptic stimulation, and both stimuli require sodium channel activation to elicit a somal calcium transient.

The contribution of the different classes of voltage-sensitive calcium channels to the somal $\left[\mathrm{Ca}^{2+}\right]_{i}$ transient following den- 
dritic stimulation differed from that following somal stimulation (Fig. 4C-E). Dihydropyridine L-type channel antagonists reduced the dendritic stimulus-induced somal $\left[\mathrm{Ca}^{2+}\right]_{i}$ transient to $53 \pm 5 \%$ of the control transient $(n=10)$, comparable to their effect on somal stimulation. $\omega$-CTx-GVIA inhibited the somal $\left[\mathrm{Ca}^{2+}\right]_{i}$ transient by $27 \%$ such that the remaining transient was $73 \pm 6 \%$ of the control transient $(n=20)$. These results show that the class $\mathrm{B}, \mathrm{C}$, and $\mathrm{D}$ calcium channels are all required for somal calcium transients when they are elicited by a distal dendritic stimulation. Addition of $\omega$-Aga-IVA (100 nM) followed by $\omega$-CTx-MVIIC $(1.5 \mu \mathrm{M})$ further reduced the somal $\left[\mathrm{Ca}^{2+}\right]_{i}$ transient to $33 \pm 7 \%$ of the control transient $(n=9)$. Thus, the two antagonists of class A calcium channels inhibit $40 \%$ of the somal $\left[\mathrm{Ca}^{2+}\right]_{i}$ transient following apical dendritic stimulation.

Separation of the contributions of P-type and Q-type calcium currents to somal $\left[\mathrm{Ca}^{2+}\right]_{\mathrm{i}}$ transients

P-Type channels in Purkinje cells and other central neurons are preferentially inhibited by a low concentration of $\omega$-Aga-IVA $\left(\mathrm{EC}_{\mathrm{s0}}=2 \mathrm{nM}\right.$, Mintz et al., 1992a,b) while Q-type channels are inhibited by higher concentrations in cerebellar granule cells or Xenopus oocytes (Sather et al., 1993; Randall et al., 1995). In the experiments presented in Figure 3, addition of $\omega$-Aga-IVA $(100 \mathrm{nM})$ in the presence of $\omega$-CTx-GVIA reduced the stimulusinduced somal $\left[\mathrm{Ca}^{2+}\right]_{i}$ transient only slightly to $93 \pm 5 \%$ of the control (data not shown). These results suggest that most of the class A calcium channels which contribute to the somal calcium transient have relatively low affinity for $\omega$-Aga-IVA, consistent with the properties of Q-type channels as defined in previous work (Sather et al., 1993; Randall et al., 1995). In the experiments of Figure 4, addition of $\omega$-Aga-IVA (100 nM) in the presence of $\omega$-CTx-GVIA reduced the somal $\left[\mathrm{Ca}^{2+}\right]_{i}$ transient elicited by distal dendritic stiimulation by $20 \%(n=5, p<0.01$, data not shown). To investigate in more detail whether this component of the $\left[\mathrm{Ca}^{2+}\right]_{i}$ transient was due to P-type or Q-type calcium channels or both, we tested the effects of increasing concentrations of $\omega$-Aga-IVA on the dendritic stimulus-induced somal $\left[\mathrm{Ca}^{2+}\right]_{i}$ transient (Fig. 5). The threshold concentration of $\omega$-Aga-IVA necessary to reduce the somal $\left[\mathrm{Ca}^{2+}\right]_{i}$ transient was between $30 \mathrm{~nm}$ and $100 \mathrm{nM}$, indicating that there was only a small contribution of P-type channels $\left(\mathrm{EC}_{50}=2 \mathrm{nM}\right)$ to this $\left[\mathrm{Ca}^{2+}\right]_{i}$ transient. The $\mathrm{EC}_{50}$ for the inhibition of the $\left[\mathrm{Ca}^{2+}\right]_{i}$ transients was between $100 \mathrm{nM}$ and $150 \mathrm{nM}$. This is most consistent with the conclusion that the primary effect of $\omega$-Aga-IVA on calcium transients elicited by apical dendritic stimulation reflects inhibition of Q-type calcium channels, since these channels are inhibited half-maximally by 100-200 nM $\omega$-Aga-IVA when recorded from cerebellar granule cells or from Xenopus oocytes expressing $\alpha 1_{\mathrm{A}}$ cDNA (Sather et al., 1993; Randall et al., 1995).

\section{Presynaptic and postsynaptic actions of calcium channels in somal calcium transients elicited by apical dendritic stimulation}

The apical dendritic stimulation of somal $\left[\mathrm{Ca}^{2+}\right]_{i}$ transients has two components: direct dendritic stimulation and glutamate-mediated synaptic stimulation due to evoked release of glutamate from nerve terminals in the stimulus field. Therefore, the inhibition of the stimulus-induced somal $\left[\mathrm{Ca}^{2+}\right]_{i}$ transient by the calcium channel antagonists could result either from the inhibition of presynaptic glutamate release and/or the inhibition of postsynaptic apical dendritic calcium channels. To determine which classes of calcium channels contribute to the somal $\left[\mathrm{Ca}^{2+}\right]_{i}$ tran-
Figure 5.
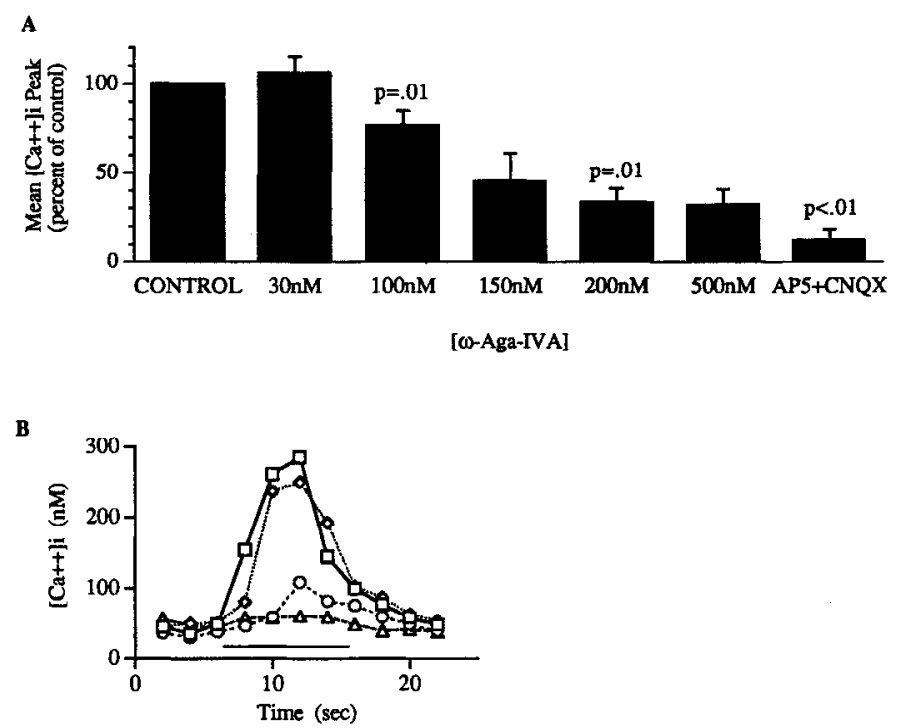

Figure 5. Effects of increasing concentrations of $\omega$-Aga-IVA on the somal $\left[\mathrm{Ca}^{2+}\right]_{i}$ transient elicited by distal dendritic stimulation. $A$, The somal $\left[\mathrm{Ca}^{2+}\right]_{i}$ transient was measured during apical dendritic stimulation in the presence of the indicated concentrations of $\omega$-Aga-IVA or in the presence of $500 \mathrm{nM} \omega$-Aga-IVA and AP5 + CNQX. B, Representative somal $\left[\mathrm{Ca}^{2+}\right]_{i}$ transients for control $(\square), 100 \mathrm{nM} \omega$-Aga-IVA $(\diamond), 200$ nM $\omega$-Aga-IVA $(O)$, and $500 \mathrm{nM} \omega$-Aga-IVA and AP5 + CNQX $(\triangle)$ from experiments presented in $A$. Statistical comparisons indicated above each bar were made as follows: $30 \mathrm{nM}$ versus control; $100 \mathrm{nM}$ versus $30 \mathrm{nM} ; 150 \mathrm{nM}$ versus $100 \mathrm{nM} ; 200 \mathrm{nM}$ versus $150 \mathrm{nM} ; 500 \mathrm{nM}$ versus $200 \mathrm{nM}$; and AP5+CNQX and $500 \mathrm{~nm} \omega$-Aga-IVA versus 500 nM $\omega$-Aga-IVA.

sient resulting from direct dendritic stimulation, we tested whether the calcium channel antagonists were still effective at reducing the somal $\left[\mathrm{Ca}^{2+}\right]_{i}$ transient in the presence of AP5 and CNQX to block synaptic transmission (Fig. 6). The L-type channel antagonists isradipine or nimodipine inhibited the somal $\left[\mathrm{Ca}^{2+}\right]_{i}$ transient by about $40 \%$ such that the remaining transient was $61 \pm 12 \%(n=14)$ of the control transient, which was comparable to the level of inhibition observed without inhibition of synaptic transmission. These results indicate that the class $\mathrm{C}$ and D L-type calcium channels contribute directly to somal $\left[\mathrm{Ca}^{2+}\right]_{i}$ transients and do not contribute significantly to glutamate-mediated synaptic transmission under these conditions. In contrast, $\omega$-CTx-GVIA was no longer effective at inhibiting the somal $\left[\mathrm{Ca}^{2+}\right]_{i}$ transient $(n=16)$, indicating that the entire effect of the N-type channel antagonist on calcium transients elicited by apical dendritic stimulation was due to inhibition of glutamatergic synaptic transmission. Evidently, class B N-type calcium channels in the dendritic shaft do not contribute significantly to the the activation of somal $\left[\mathrm{Ca}^{2+}\right]_{i}$ transients elicited by distal dendritic stimulation, but do contribute significantly to glutamatergic transmission at the excitatory synapses on the distal CA3 dendrites.

Surprisingly, $\omega$-Aga-IVA (100 nM) increased the somal $\left[\mathrm{Ca}^{2+}\right]_{i}$ transient elicited by apical dendritic stimulation to 198 $\pm 31 \%$ of the control transient after block of excitatory transmission (Fig. 6, $n=12$ ). It is likely that this increase reflects block of tonic release of the inhibitory transmitter GABA by $\omega$-Aga-IVA, thus allowing more efficient activation of the cell (see Discussion). Further addition of $\omega$-CTx-MVIIC had no effect on the somal $\left[\mathrm{Ca}^{2+}\right]_{i}$ transient $(n=5)$. These results indicate 
Figure 6.

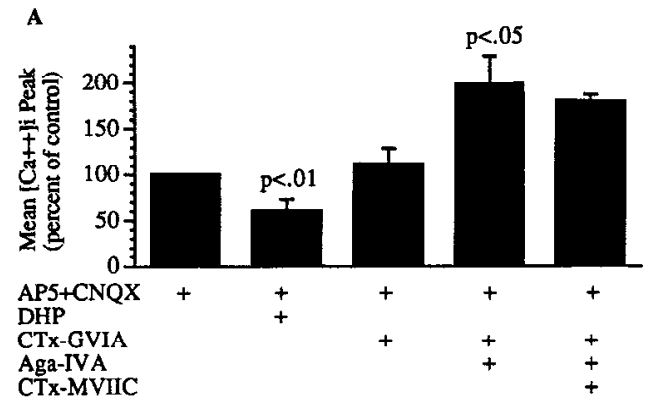

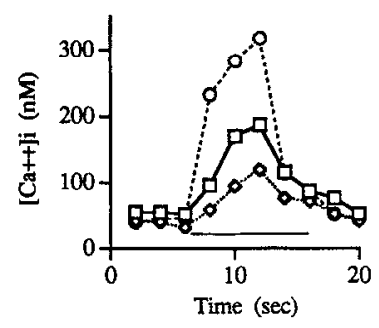

Figure 6. Class B N-type and class A P/Q-type calcium channels contribute to glutamate-mediated synaptic transmission. A, Glutamate-mediated synaptic transmission was inhibited and the effects of each calcium channel antagonist on the remaining somal $\left[\mathrm{Ca}^{2+}\right]_{i}$ transient were then measured during apical dendritic stimulation. Data are expressed as the mean $\left[\mathrm{Ca}^{2+}\right]_{\text {, peak }}$ as a percentage of the response obtained with AP-5 and CNOX present. The inhibitory effects of the class A channel antagonists ( $\omega$-Aga-IVA and $\omega$-CTx-MVIIC) and the class B channel antagonist ( $\omega$-CTxGVIA) on the somal $\left[\mathrm{Ca}^{2+}\right]_{i}$ transient were occluded in the absence of glutamate-mediated synaptic transmission. $\omega$-Aga-IVA increased the somal $\left[\mathrm{Ca}^{2+}\right]_{i}$ transient. In contrast, DHPs effectively reduced the somal $\left[\mathrm{Ca}^{2+}\right]_{i}$ transient even in the absence of glutamate-mediated synaptic transmission $B$, Representative somal $\left[\mathrm{Ca}^{2+}\right]_{i}$ transients for AP5 + CNQX $(\square)$, AP5 + CNQX and DHP $(\diamond)$, and AP5 + CNQX, $\omega$-CTX-GVIA, and $\omega-\mathrm{Aga}-$ IVA $(O)$ from the experiments presented in $A$. Statistical comparisons indicated above each bar were made as follows with AP5 + CNQX in all samples: DHP versus none; $\omega$-CTx-GVIA versus none; $\omega$-Aga-IVA and $\omega$-CTx-GVIA versus $\omega$-CTx-GVIA; and $\omega$-CTx-MVIIC, $\omega$ - $\Lambda$ ga-IVA, and $\omega$-CTx-GVIA versus $\omega$-Aga-IVA and $\omega$-CTx-GVIA

that the reduction of calcium transients by $\omega$-CTX-MVIIC following apical dendritic stimulation is also due primarily to inhibition of glutamatergic synaptic transmission rather than inhibition of class A calcium channels in the dendritic shaft. Thus, neither class A nor class B calcxium channels located in the dendritic shaft are required for activation of somal $\left[\mathrm{Ca}^{2+}\right]_{i}$ transients in response to distal dendritic stimulation, but both class $A$ and class B calcium channels are required for normal synaptic transmission at excitatory synapses on CA3 neurons.

Very little glutamate-mediated synaptic transmission remained after application of $\omega$-CTx-GVIA and $\omega$-CTx-MVIIC, as the addition of AP5 and CNQX at this point decreased the somal $\left[\mathrm{Ca}^{2+}\right]_{i}$ transient only slightly such that the remaining transient was reduced from $32 \pm 7 \%$ to $27 \pm 6 \%(p<0.05)$ of the original control transient (Fig. $4 C, n=9$; Fig. $4 E$ ). Following the addition of $500 \mathrm{nM} \omega$-Aga-IVA to block all class A channels, AP5 and CNQX still effectively decreased the somal $\left[\mathrm{Ca}^{2+}\right]_{i}$ transient such that the remaining transient was reduced from 32 $\pm 9 \%$ to $12 \pm 6 \%$ of the control transient (Fig. 5). The remaining glutamatergic transmission under these conditions is likely to be due primarily to class $\mathrm{B} N$-type channels which remain active in $500 \mathrm{~nm} \omega$-Aga-IVA. These results provide further support for the conclusion that both class $\mathrm{A}$ and class B calcium channels are critically involved in glutamate-mediated synaptic transmission as their inhibition by calcium channel antagonists occludes the effects of AP5 and CNQX on calcium transients clicited by stimulation of apical dendrites. In contrast, the class C and D L-type calcium channels do not appear to serve a major role in glutamate-mediated excitatory synaptic transmission in CA3 neurons in the cultured hippocampal slice. Antagonists of L-type calcium channels are approximately equally effective in blocking somal calcium transients whether synaptic transmission is blocked or not.

\section{Discussion}

Differential localization of calcium channel subtypes

In adult hippocampus, the calcium channel subtypes encoded by the class A through E $\alpha 1$ subunit genes are differentially localized as assessed by immunocytochemical studies with monoclo- nal and site-directed anti-peptide antibodies (Ahlijanian et al., 1990; Westenbroek et al., 1990, 1992, 1995; Hell et al., 1993). The class C and class D L-type channels are localized predominantly on the cell bodics and proximal dendrites of pyramidal neurons, although patches of class $\mathrm{C}$ channels can also be detected on medial dendrites of CA3 and dentate granule neurons (Hell et al., 1993). In contrast, class B N-type and class A P/Qtype channels are generally localized at low density along the dendrites of hippocampal pyramidal neurons with superimposed areas of high density, punctate staining that appear to be associated with presynaptic terminals. Anti-CNA1 may recognize P-type and Q-type channels as this antibody strongly binds to both cerebellar Purkinje cells which are rich in P-type channels and granule cells and their terminals which are rich in Q-type channels (Westenbroek et al., 1995).

Determination of the functional roles of these differentially localized calcium channels requires development of an in vitro experimental system in which calcium transients can be measured in minimally perturbed neurons which retain the morphology, synaptic connectivity, and physiological properties characteristic of the hippocampus in vivo. In this article, we show that the in vitro hippocampal slice culture is an appropriate experimental system for this analysis. Differential localization of class D L-type, class B N-type, and class A P/Q-type calcium channel subtypes is observed in postnatal rat hippocampal slice cultures, as in adult neurons, enabling direct comparisons between calcium channel localization and function. On the basis of these results, the experiments described here were designed to test the functional implications of the differential localization of these calcium channel subtypes and to examine whether they serve distinct roles in neuronal activation and signal transduction.

Intracellular calcium transients as a measure of neuronal calcium channel function

The functional properties of different types of calcium channels have been studied extensively using whole cell voltage-clamp procedures applied to dissociated neurons to measure barium currents in response to prolonged depolarizations of the cells 
(reviewed in Bean, 1989; Hess, 1990; Zhang et al., 1993). These studies give a clear picture of the ionic currents conducted by distinct calcium channel types in the cell bodies of central neurons. In order to examine the roles of different classes of calcium channels in regulation of cytosolic calcium levels in intact neurons, we have measured intracellular calcium transients in the cell bodies of CA3 neurons in cultured hippocampal slices in response to trains of brief stimuli which elicit synaptic activation and neuronal action potentials. The somal calcium transients that we measure are the mechanism of coupling of cell surface electrical signals to intracellular events within the cell body and therefore represent a physiologically relevant index of calcium channel function. Our results using this approach complement previous studies of calcium channel function in dissociated preparations and reveal distinct functional roles of calcium channels in different cellular compartments.

Class $C$ and $D$ L-type and class A $P / Q$-type calciurn channels are required for somal $\left[\mathrm{Ca}^{2+}\right]_{\mathrm{i}}$ transients elicited by somal stimulation

Upon direct somal stimulation, the class $C$ and D L-type and the class A P/Q-type, but not class B N-type, calcium channels mediate calcium entry into the CA3 neuronal soma. Antagonists of L-type channels inhibit $56 \%$ of the somal $\left[\mathrm{Ca}^{2+}\right]_{i}$ transient. Antagonists of class A P/Q-type channels inhibit $41 \%$ of the somal $\left[\mathrm{Ca}^{2+}\right]_{i}$ transient. $\omega$-Aga-IVA had little or no effect on directly elicited somal calcium transients at $100 \mathrm{~nm}$, a concentration which is relatively specific for P-type versus Q-type calcium channels, suggesting that most class A calcium channels participating in generation of these calcium transients in CA3 cell bodies have the pharmacological characteristics of Q-type channels. $\omega$-CTX-GVIA had no effect on the somal $\left[\mathrm{Ca}^{2+}\right]_{i}$ transient indicating no important contribution from class B N-type calcium channels.

Our results indicate that the concentration of class C and D L-type calcium channels in cell bodies allows them to play a primary role in cell body calcium transients, while the primary localization of class B N-type calcium channels in dendrites and nerve terminals prevents them from exerting a major influence on directly elicited cell body calcium transients. Class A calcium channels containing $\alpha 1_{\mathrm{A}}$ also contribute significantly to $\left[\mathrm{Ca}^{2+}\right]_{i}$ transients in cell bodies, as assessed by inhibition by $\omega$-CTXMVIIC, consistent with the intermediate somal expression of this $\alpha 1$ subunit. Glutamate receptors do not appear to mediate somal calcium influx following direct somal stimulation of C.A3 pyramidal neurons as glutamate receptor antagonists were ineffective at reducing the somal $\left[\mathrm{Ca}^{2+}\right]_{i}$ transients. The cell bodies of CA1 hippocampal neurons are also unresponsive to glutamate receptor antagonists (Alford et al., 1993).

The presence of class C and D L-type and class A P/Q-type calcium channels on neuronal cell bodies and their primary role in generation of cell body $\left[\mathrm{Ca}^{2+}\right]_{i}$ transients indicates their probable involvement in calcium-dependent events such as the regulation of enzyme activity and gene expression. L-Type channels have been shown to participate in both of these calcium-dependent events in other cell preparations (e.g., Kennedy, 1989; Murphy et al., 1991).

Class B N-type and class A P/Q-type calcium channels participate in presynaptic release of glutamate

Antagonists of $N$-type calcium channels containing $\alpha 1_{B}$ and P/Q-type calcium channels containing $\alpha 1_{A}$ significantly inhibit somal calcium transients elicited by apical dendritic stimulation. However, their inhibition is completely occluded following the blockade of excitatory synaptic transmission with AP5 and CNQX. These results demonstrate an essential role of calcium channels containing $\alpha 1_{\mathrm{A}}$ and $\alpha 1_{\mathrm{B}}$ in synaptic transmission onto CA3 neurons in cultured hippocampal slices. These results correlate well with the localization of these two calcium channel types in punctate clusters in presynaptic nerve terminals at synapses on both CA1 and CA3 pyramidal neurons (Westenbroek et al., 1992, 1995).

Previous studies have shown that calcium channels inhibited by $\omega$-CTX-GVIA and by $\omega$-CTX-MVIIC or high concentrations of $\omega$-Aga-IVA are important for synaptic transmission from the Schaffer collaterals of the CA3 neurons to the CA1 pyramidal neurons (Dutar et al., 1989; Luebke et al., 1993; Takahashi and Momiyama, 1993; Wheeler et al., 1994) and for transmission from the mossy fibers of the dentate granule cells to the proximal dendrites of CA3 pyramidal neurons (Kamiya et al., 1988). Our results show that class $B$ N-type and class A P/Q-type calcium channels are also important for synaptic transmission onto the distal dendrites of CA3 neurons in organotypic hippocampal slice cultures. Together with previous studies, our results support the conclusion that class B N-type and class A P/Q-type calcium channels are important in synaptic transmission at a broad range of synapses on central neurons.

In contrast to the results with antagonists of N-type and P/Qtype calcium channels, we have not observed a significant contribution of L-type calcium channels to glutamate-mediated synaptic transmission. Antagonists of L-type calcium channels reduce somal calcium transients induced by apical dendritic stimulation substantially in the presence or absence of blockers of excitatory transmission. It is likely that these inhibitory effects are due to block of the L-type calcium channels in the proximal dendrites and cell body which are directly responsible for calcium entry into the cell soma. This conclusion is consistent with immunocytochemical results showing that the L-type channel $\alpha 1$ subunits are primarily localized in the cell body and proximal apical dendrites.

Luebke et al. (1993) reported that $100 \mathrm{nM} \omega$-Aga-IVA enhanced postsynaptic responses to applied AMPA in CA1 neurons. Similarly, we found that $100 \mathrm{nM} \omega$-Aga-IVA potentiated the somal $\left[\mathrm{Ca}^{2+}\right]_{i}$ transient in CA3 neurons following inhibition of glutamate-mediated synaptic transmission. In our study, we inhibited AMPA receptor function with CNQX excluding a major direct effect of $\omega$-Aga-IVA on AMPA-sensitive glutamate receptors. Instead, P-type channels may be involved in release of other neurotransmitters in the hippocampal slice cultures which alter the $\left[\mathrm{Ca}^{2+}\right]_{i}$ transient elicited by distal dendritic stimulation. For example, P-type channels may initiate GABA release from inhibitory interneurons within the hippocampal slice cultures such that $100 \mathrm{nM} \omega$-Aga-IVA, which inhibits P-type calcium currents relatively specifically, causes a relief of inhibitory input to the $\mathrm{CA} 3$ neurons and thereby potentiates their $\left[\mathrm{Ca}^{2+}\right]_{i}$ transients elicited by direct depolarization while excitatory transmission is blocked. These inhibitory effects are apparently small since they do not appear to affect somal calcium transients elicited by distal dendritic stimulation when excitatory neurotransmission is intact (Fig. 5). Nevertheless, these effects of low concentrations of $\omega$-Aga-IVA in the presence of AP5 and CNQX point to an important caveat for interpretation of pharmacological studies in complex preparations like the hippocampal slice. It is possible that the pharmacological agents we used 
in these studies have undetected effects on interneurons which alter ongoing synaptic transmission onto CA3 neurons and indirectly influence their responses to distal dendritic stimuli. Because these indirect effects were only revealed when excitatory transmission was blocked, it seems unlikely that they are large enough to affect the main conclusions of this study. However, indirect effects of the calcium channel blockers on synaptic transmission from interneurons may well have influenced the quantitative aspects of the results.

\section{High-voltage-activated dendritic calcium channels are not required for activation of cell body calcium transients by distal dendritic stimulation}

Calcium-dependent action potentials can be recorded in the dendrites of many central neurons including cerebellar Purkinje cells (Llinas and Sugimori, 1979) and hippocampal pyramidal neurons (Wong et al., 1979). Therefore, it has been anticipated that the calcium-dependent action potentials would be essential for transmission of synaptic responses along the dendrites to the cell body, at least in long dendrites like those of the CA3 neurons studied here (Llinas and Sugimori, 1979). In contrast to this expectation, inhibition of the class A and B calcium channels that have been shown to be located on dendrites in immunocytochemical studies did not alter somal $\left[\mathrm{Ca}^{2+}\right]_{i}$ transients following dendritic stimulation. Thus, the effects of antagonists of both class $A$ and class $B$ calcium channels on somal $\left[\mathrm{Ca}^{2+}\right]_{i}$ transients elicited by distal dendritic stimuli were completely occluded by inhibition of excitatory glutamatergic transmission indicating that only the presynaptic class A and class B calcium channels were involved. Since block of excitatory transmission would make the activation of the postsynaptic CA3 neurons even more sensitive to inhibition of postsynaptic dendritic calcium channels, our experiments should have detected contributions of the high-voltage-activated dendritic channcls if they were significant. We conclude that high-voltage-activated dendritic calcium channels do not have a major role in transmitting synaptic input to the cell body when strong, synchronous stimuli are applied to the distal dendrites as in our experiments.

In neocortical neurons, low-voltage-activated dendritic calcium channels generate a $\left[\mathrm{Ca}^{2+}\right]_{i}$ transient, in response to a single subthreshold dendritic EPSP, that may propagate toward the soma (Markram and Sakmann, 1994). Although we have not resolved a role for high-voltage-activated dendritic calcium channels in transmission of synaptic stimuli to the cell body in these experiments, we cannot rule out an essential role for them in the response of the CA3 neurons to individual or nonsynchronous synaptic stimuli or to low intensity synaptic stimuli as are likely to occur in many circumstances in vivo. Dendritic calcium-dependent action potentials may allow summation of such subthreshold synaptic stimuli to reach the level of depolarization required for action potential generation or to modulate the frequency of action potential generation. The dendritic calcium channels may also function to increase local calcium in the dendrites initiating local intracellular regulatory events. These are likely to include activation of calcium-dependent protein kinases resulting in protein phosphorylation and cellular regulation.

\section{Role of sodium channels in mediation of CA3 neuronal calcium transients}

We found that sodium channel inhibition blocks $90 \%$ of the somal $\left[\mathrm{Ca}^{2+}\right]_{i}$ transient following either apical dendritic or direct somal stimulation. Evidently, sodium channels are essential for initiation of neuronal calcium transients following trains of strong stimuli in CA3 neurons in the organotypic hippocampal slice as was previously demonstrated for CA1 neurons (Jaffe et al., 1992; Miyakawa et al., 1992; Regehr and Tank, 1992). We interpret these results in light of the recent findings of Stuart and Sakmann (1994) on sodium-dependent action potentials in dendrites. They recorded sodium-dependent action potentials blocked by low concentrations of tetrodotoxin in the distal apical dendrites of cortical pyramidal cells in acute slice preparations. These action potentials were initiated in the axon initial segment and propagated in the retrograde direction into the dendrites. They were elicited by synaptic stimuli as well as by direct depolarization of the dendrites. These results suggest that cortical neurons are sufficiently electrically compact that strong stimuli to the distal dendrites can elicit an action potential in the axon initial segment by electrotonic conduction. By analogy, we hypothesize that our apical dendritic stimuli clicit sodium-dependent action potentials initiated in the axon initial segment, and these action potentials in turn are responsible for the cell body calcium transients that we have recorded. Thus, at least in response to strong trains of stimuli as used here, activation of sodium channels in the axon initial segment apparently is critical for generation of a cell body calcium transient in response to both direct stimulation of the cell body and indirect stimulation of the distal dendrites.

\section{Distinct roles for the calcium channel classes}

Based upon the differential subcellular localization of the calcium channel subtypes within the neuron, it was predicted (Ahlijanian et al., 1990; Westenbroek et al., 1990, 1992, 1995) that each channel subtype would serve a distinct role in neuronal signal transduction. We have shown this to be true for the CA3 hippocampal neuron. Following somal stimulation, only those channels whose $\alpha 1$ subunit was found to be localized to the cell body (class $\mathrm{A}, \mathrm{C}$, and $\mathrm{D}$, but not class $\mathrm{B}$ ), contributed significantly to the somal $\left[\mathrm{Ca}^{2+}\right]_{i}$ transient and did so in a manner related to their relative abundance on the cell body. These channels may regulate such somal processes as enzyme activation and gene induction. Following apical dendritic stimulation, only those channels whose $\alpha 1$ subunit was found to be localized to synaptic structures on the medial-distal apical dendrites (class A and $B$, but not class $C$ and D), contributed to glutamate-mediated synaptic transmission. Further information on the role of each calcium channel subtype in signal transduction in neurons will come from determination of the contribution of each calcium channel subtype to the $\left[\mathrm{Ca}^{2+}\right]_{i}$ transients recorded in the medialdistal apical dendrite. The value of the approach utilized in this study is that direct comparisons can be made between calcium channel subtype localization and function in the same intact neuron. This approach may also be useful for determination of the contribution of these channels to calcium transients in dendrites.

\section{References}

Ahlijanian MK, Westenbroek RE, Catterall WA (1990) Subunit structure and localization of dihydropyridine-sensitive calcium channels in mammalian brain, spinal cord, and retina. Neuron 4:819-832.

Alford S, Frenguelli BG, Schofield JG, Collingridge GL (1993) Characterization of $\mathrm{Ca}^{2+}$ signals induced in hippocampal CA1 neurones by the synaptic activation of NMDA receptors. J Physiol (Lond) 469: 693-716.

Bean BP (1989) Classes of calcium channels in vertebrate cells. Annu Rev Physiol 51:367-384. 
Campbell KP, Leung AT, Sharp AH (1988) The biochemistry and molecular biology of the dihydropyridine-sensitive calcium channel. Trends Neurosci 11:425-430.

Catterall WA, Seagar MJ, Takahashi M (1988) Molecular properties of dihydropyridine-sensitive calcium channels in skeletal muscle. J Biol Chem 263:3535-3538.

Dailey ME, Buchanan J, Bergles DE, Smith SJ (1994) Mossy fiber growth and synaptogenesis in rat hippocampal slices in vitro. J Neurosci 14:1060-1078.

Dubel SJ, Starr TVB, Hell J, Ahlijanian MK, Enyeart JJ, Catterall WA, Snutch TP (1992) Molecular cloning of the $\alpha-1$ subunit of an $\omega$-conotoxin-sensitive calcium channel. Proc Natl Acad Sci USA 89:50585062

Dutar P, Rascol O, Lamour Y (1989) $\omega$-Conotoxin GVIA blocks synaptic transmission in the CA1 field of the hippocampus. Eur J Pharmacol 174:261-266.

Elliott E, Sapolsky R (1992) Corticosterone enhances kainic acid-induced calcium elevation in cultured hippocampal neurons. J Neurochem 59:1033-1040.

Elliott E, Sapolsky R (1993) Corticosterone impairs hippocampal neuronal calcium regulation-possible mediating mechanisms. Brain Res 602:84-90.

Frotscher M, Gähwiler BH (1988) Synaptic organization of intracellularly stained CA3 pyramidal neurons in slice cultures of rat hippocampus. Neuroscience 24:541-551.

Fujita Y, Mynlieff M, Dirksen RT, Kim MS, Niidome T, Nakai J, Friedrich T, Iwabe N, Miyata T, Furuichi T, Furutama D, Mikoshiba D, Mori Y, Beam KG (1993) Primary structure and expression of the $\omega$-conotoxin-sensitive $\mathrm{N}$-type calcium channel from rabbit brain. Neuron 10:585-598.

Gähwiler BH (1981) Organotypic monolayer cultures of nervous tissue. J Neurosci Methods 4:329-342.

Grynkiewicz G, Poenie M, Tsien R (1985) A new generation of $\mathrm{Ca}^{2+}$ indicators with greatly improved fluorescence properties. J Biol Chem 260:3440-3450.

Hell JW, Westenbroek RE, Warner C, Ahlijanian MK, Prystary W, Gilbert MM, Snutch TP, Catterall WA (1993) Identification and differential subcellular localization of the neuronal class $C$ and class D L-type calcium channel $\alpha 1$ subunits. J Cell Biol 123:949-962.

Hess P (1990) Calcium channels in vertebrate cells. Annu Rev Neurosci 13:337-356.

Hillman D, Chen S, Aung TT, Cherskey B, Sugimori M, Llinas RR (1991) Localization of P-type calcium channels in the central nervous system. Proc Natl Acad Sci USA 88:7076-7080.

Hillyard DR, Monje VD, Mintz IM, Bean BP, Nadasdi L, Ramachandran J, Miljanich G, Azimi-Zoonooz A, McIntosh JM, Cruz LJ, Imperial JS, Olivera BM (1992) A new Conus peptide ligand for mammalian presynaptic $\mathrm{Ca}^{2+}$ channels. Neuron 9:69-77.

Hui A, Ellinor PT, Krizanova O, Wang JJ, Diebold RJ, Schwartz A (1991) Molecular cloning of multiple subtypes of a novel rat brain isoform of the $\alpha 1$ subunit of the voltage-dependent calcium channel. Neuron 7:35-44.

Jaffe DB, Johnston D, Lasser-Ross N, Lisman JE, Miyakawa H, Ross WN (1992) The spread of $\mathrm{Na}^{+}$spikes determines the pattern of dendritic $\mathrm{Ca}^{2+}$ entry into hippocampal neurons. Nature 357:244-246.

Kamiya H, Sawada S, Yamamoto C (1988) Synthetic $\omega$-conotoxin blocks synaptic transmission in the hippocampus in vitro. Neurosci Lett 91:84-88.

Kennedy MB (1989) Regulation of neuronal function by calcium. Trends Neurosci 12:417-420.

Leveque C, El Far O, Martin-Moutot N, Sato K, Kato R, Takahashi M, Seagar M (1994) Purification of the N-type calcium channel associated with syntaxin and synaptotagmin: a complex implicated in synaptic vesicle exocytosis. J Biol Chem 269:6306-6312.

Llinas R, Sugimori M (1979) Calcium conductances in purkinje cell dendrites: their role in development and integration. Prog Brain Res 51:323-334.

Llinas R, Sugimore M, Lin JW, Cherksey B (1989) Blocking and isolation of a calcium channel from neurons in mammals and cephalopds utilizing a toxin fraction (FTX) from funnel-web spider poison. Proc Natl Acad Sci USA 86:1689-1693.

Luebke JI, Dunlap K, Turner TJ (1993) Multiple calcium channel types control glutamatergic synaptic transmission in the hippocampus. Neuron 11:895-902.

Malouf AT, Robbins CA, Schwartzkroin PA (1990) Phaclofen inhibi- tion of the slow inhibitory postsynaptic potential in hippocampal slice cultures: a possible role for the $\mathrm{GABA}_{\mathrm{B}}$-mediated inhibitory postsynaptic potential. Neurosci 35:53-61.

Markram H, Sakmann B (1994) Calcium transients in dendrites of neocortical neurons evoked by single subthreshold excitatory postsynaptic potentials via low-voltage-activated calcium channels. Proc Natl Acad Sci USA 91:5207-5211.

McEnery MW, Snowman AM, Sharp AH, Adams ME, Snyder SH (1991) Purified $\omega$-conotoxin GVIA receptor of rat brain resembles a dihydropyridine-sensitive L-type calcium channel. Proc Natl Acad Sci USA 88:11095-11099.

Mikami A, Imoto K, Tanabe T, Niidome T, Mori Y, Takeshima H, Narumiya S, Numa $S$ (1989) Primary structure and functional expression of the cardiac dihydropyridine-sensitive calcium channel, Nature 340:230-233.

Mintz IM, Venema VJ, Swiderek K, Lee T, Bean BP, Adams ME (1992a) P-Type calcium channels blocked by the spider toxin $\omega$-AgaIVA. Nature 355:827-829.

Mintz IM, Adams ME, Bean BP (1992b) P-type calcium channels in rat central and peripheral neurons. Neuron 9:85-95.

Miyakawa H, Ross WN, Jaffe D, Callaway JC, Lasser-Ross N, Lisman JE, Johnston D (1992) Synaptically activated increases in $\mathrm{Ca}^{2+}$ concentration in hippocampal CA1 pyramidal cells are primarily due to voltage-gated $\mathrm{Ca}^{\text {p+ }}$ channels. Neuron 9:1163-1173.

Murphy TH, Worley PF, Baraban JM (1991) L-Type voltage-sensitive calcium channels mediate synaptic activation of immediate early genes. Neuron 7:625-635

Perez-Reyes E, Kim HS, Lacerda AE, Horne W, Wei XY, Rampe D, Campbell KP, Brown AM, Birnbaumer L (1989) Induction of cal cium currents by the expression of the alphal-subunit of the dihydropyridine receptor from skeletal muscle. Nature 340:233-236.

Randall A, Tsien RW (1995) Pharmacological dissection of multiple types of $\mathrm{Ca}^{2+}$ channel currents in rat cerebellar granule neurons. $\mathrm{J}$ Neurosci, in press.

Regehr WG, Tank DW (1992) Calcium concentration dynamics produced by synaptic activation of CA1 hippocampal pyramidal cells. J Neurosci 12:4202-4223.

Regehr WG, Connor JA, Tank DW (1989) Optical imaging of calcium accumulation in hippocampal pyramidal cells during synaptic activation. Nature 341:533-536.

Sather WA, Tanabe T, Zhang J-F, Mori Y, Adams ME, Tsien RW (1993) Distinctive biophysical and pharmacological properties of Class A (B1) calcium channel $\alpha 1$ subunits. Neuron 11:291-303.

Snutch TP, Reiner PB (1992) Calcium channels: diversity of form and function. Curr Opin Neurobiol 2:247-253.

Snutch TP, Leonard JP, Gilbert MM, Lester HA, Davidson N (1990) Rat brain expresses a heterogeneous family of calcium channels. Proc Natl Acad Sci USA 87:3391-3395.

Soong TW, Stea A, Hodson CD, Dubel SJ, Vincent SR, Snutch TP (1993) Structure and functional expression of a member of the lowvoltage-activated calcium channel family. Science 260:1133-1136.

Stea A, Tomlinson WJ, Soong TW, Bourinet E, Dubel SJ, Vincent SR, Snutch TP (1994) The localization and functional properties of a rat brain alA calcium channel reflect similarities to neuronal $Q$ - and P-type channels. Proc Natl Acad Sci USA 91:10576-10580.

Stuart GJ, Sakmann B (1994) Active propagation of somatic action potentials into neocortical pyramidal cell dendrites. Nature 367:6972.

Takahashi T, Momiyama A (1993) Different types of calcium channels mediate central synaptic transmission. Nature 366:156-158.

Tomlinson WJ, Stea A, Bourinet E, Charnet P, Nargeot J, Snutch TP (1993) Functional properties of aneuronal class C L-type calcium channel. Neuropharmacology 32:1117-1126.

Usowicz M, Sugimori M, Cherksey B, Llinas R (1992) P-type calcium channels in the somata and dendrites of adult cerebellar Purkinje cells. Neuron 9:1185-1199.

Westenbroek RE, Ahlijanian MK, Catterall WA (1990) Clustering of L-type $\mathrm{Ca}^{2+}$ channels at the base of major dendrites in hippocampal pyramidal neurones. Nature 347:281-284.

Westenbroek RE, Hell JW, Warner C, Dubel SJ, Snutch TP, Catterall WA (1992) Biochemical properties and subcellular distribution of an N-type calcium channel $\alpha 1$ subunit. Neuron 9:1099-1115.

Westenbroek RE, Sakurai T, Elliott EM, Hell JW, Starr TVB, Snutch TP, Catterall WA (1995) Immunochemical identification and sub- 
cellular distribution of the $\alpha_{1 \mathrm{~A}}$ subunits of brain calcium channels. J Neurusci 15:6403-6418.

Wheeler DB, Randall A, Tsien RW (1994) Roles of N-type and Q-type $\mathrm{Ca}^{2+}$ channels in supporting hippocampal synaptic transmission. Science 264:107-111.

Williams ME, Feldman DH, McCue AF, Brenner R, Velicelebi G, Ellis SB, Harpold MM (1992a) Structure and functional expression of $\alpha_{1}$, $\alpha_{2}$, and $\beta$ subunits of a novel human neuronal calcium channel subtype. Neuron 8:71-84.

Williams ME, Brust BF, Feldman DII, Patthi S, Smerson S, Maroufi A, McCue AF, Velicelebi G, Ellis SB, Harpold MM (1992b) Structure and functional expression of an $\omega$-conotoxin-sensitive human N-type calcium channel. Science 257:389-395.

Witcher DR, De Waaard M, Sakamoto J, Franzini-Armstrong C, Pragnell M, Kahl SD, Campbell KP (1993) Subunit identification and reconstitution of the $\mathrm{N}$-type $\mathrm{Ca}^{2+}$ channel complex purified from brain. Science 261:486-489.

Wong RKS, Prince DA, Basbaum AI (1979) Intradendritic recordings from hippocampal neurons. Proc Natl Acad Sci USA 76:986-990.

Zhang JF, Randall AD, Ellinor PT, Horne WA, Sather WA, Tanabe T, Schwartz TL, Tsien RW (1993) Distinctive pharmacology and kinetics of cloned neuronal calcium channels and their possible counterparts in mammalian CNS neurons. Neuropharmacology 32:1075-1088. 